\title{
Inclusão socioprodutiva na gestão de resíduos sólidos em municípios do estado de Mato Grosso, Brasil
}

O objetivo do estudo foi de identificar os limites e as possibilidades da Política Nacional de Resíduos Sólidos (PNRS) no que diz respeito à coleta seletiva com a inclusão socioprodutiva de Catadores/as de materiais recicláveis nos municípios do Estado de Mato Grosso, à luz da PNRS/2010. A metodologia segue as orientações de Minayo (1994), Richardson (1985) e Bardin (2009), trata-se de uma pesquisa qualitativa, descritiva. As evidências empíricas deste artigo são oriundas de pesquisa de campo e de pesquisa documental. Utilizou-se técnica de análise de conteúdo. Os achados apontam que a coleta seletiva é uma possibilidade sustentável de desenvolvimento econômico, social e ambiente para os municípios, além de proteger o meio ambiente, movimenta a economia gera trabalho decente com a contratação de cooperativas ou associação de Catadores/as de materiais recicláveis formadas por pessoas físicas de baixa renda em consonância com a PNRS. Mostram, também, avanços na contratação de Catadores/as, quantidade significativa de materiais direcionados à reciclagem, que deixam de se tornar passivo ambiental, e avanços na autogestão de associações e cooperativas. Apesar disso, existem limitações, oriundas, em sua maioria, dos parcos recursos investidos na política pública de gestão integrada de resíduos sólidos, especialmente para a coleta seletiva, poucos investimentos nas Organizações de Catadores/as, em ações de educação ambiental.

Palavras-chave: PMGIRS; Gestão de Resíduos Sólidos; GRSU; Leis Municipais.

\section{Socio-productive inclusion in solid waste management in municipalities of the state of Mato Grosso, Brazil}

The objective of the study was to identify the limits and possibilities of the National Solid Waste Policy (NSWP) with reference to selective collection with the socio-productive inclusion of waste pickers in the municipalities of the State of Mato Grosso, according to the PNRS/2010. The methodology follows the guidelines of Minayo (1994), Richardson (1985) and Bardin (2009), it is a qualitative, descriptive research. The empirical evidences of this article come from field research and documentary research. Content analysis technique was used. The findings point out that selective collection is a sustainable possibility of economic, social and environmental development for the municipalities, besides protecting the environment, it moves the economy, generates decent work by hiring cooperatives or an association of recyclable material collectors formed by low-income individuals in line with the PNRS. They also show advances in the hiring of waste pickers, a significant amount of materials directed to recycling, which cease to become environmental liabilities, and advances in the self-management of associations and cooperatives. Despite this, there are limitations, mostly coming from the scarce resources invested in the public policy of integrated solid waste management, especially for selective collection, few investments in Waste Pickers Organizations, in environmental education actions.

Keywords: PMGIRS; Solid Waste Management; GRSU; Municipal Laws.

Topic: Planejamento, Gestão e Políticas Públicas Ambientais

Reviewed anonymously in the process of blind peer.
Received: 24/04/2021

Approved: 25/05/2021
Sonia Aparecida Beato Ximenes de Melo (iD)

Universidade do Estado de Mato Grosso, Brasil

http://lattes.cnpq.br/3161014550783130

http://orcid.org/0000-0001-9142-5941

msc.soniaximenes@gmail.com

Sandro Benedito Sguarezi

Universidade do Estado de Mato Grosso, Brasil

http://lattes.cnpq.br/6517662915137218

http://orcid.org/0000-0001-7361-8977

sandrosguarezi@gmail.com

Andre Ximenes Melo

Universidade do Estado de Mato Grosso, Brasil

http://lattes.cnpq.br/3034808713550502

http://orcid.org/0000-0001-7411-1836

msc.andreximenes@gmail.com
Referencing this:

MELO, S. A. B. X.; SGUAREZI, S. B.; MELO, A. X.. Inclusão socioprodutiva na gestão de resíduos sólidos em municípios do estado de Mato Grosso, Brasil. Revista Ibero Americana de Ciências Ambientais, v.12, n.5, p.632-654, 2021. DOI: http://doi.org/10.6008/CBPC2179-6858.2021.005.0050 


\section{INTRODUÇÃO}

O modelo de desenvolvimento atual empurrou a sociedade para a lógica do consumo, ancorada na exploração de recursos naturais (COSTA et al., 2020; DOWBOR, 2020; LEFF, 2002). É perceptível que nos últimos anos tem ocorrido uma sensível evolução na degradação ambiental, concomitantemente à urbanização, à industrialização e ao crescimento demográfico, aliados ao crescimento econômico, os quais contribuem para o aumento dos impactos ambientais negativos, principalmente por meio de geração de resíduos sólidos, visto que a sociedade se percebe consumista (APARCANA, 2017; CLEARY, 2009; HOORNWEG et al., 2012), bem como impactos sociais e econômicos (LOHRI et al., 2014).

A quantidade global de resíduos sólidos urbanos (RSU) gerados a cada ano é de 1,3 bilhão de toneladas, o que representa 1,2 quilo por dia de resíduos por pessoa. Com o rápido crescimento populacional, se espera que essa quantidade possa evoluir até 2,2 bilhões de toneladas ao ano em 2025 (HOORNWEG, 2012; RIBEIRO et al., 2017. A gestão e a disposição inadequadas desses resíduos causam diversos impactos socioeconômicos ambientais, principalmente a degradação do solo, o comprometimento dos corpos d'água e mananciais, a contribuição para a poluição do ar e proliferação de vetores de importância sanitária nos centros urbanos, além da catação de resíduos em condições insalubres nos logradouros públicos e nas áreas de disposição final (APARCANA, 2017; JACOBI et al., 2014; OLIVEIRA et al., 2018).

Nas últimas décadas surgiram inovações significativas na gestão de resíduos para atender à crescente demanda por matérias-primas com o intuito de neutralizar os impactos ambientais e sociais das economias baseadas no consumo (OLIVEIRA, 2019; PAES et al., 2020). Países com maiores estruturas econômicos criaram legislações específicas e adotaram práticas de logística reversa. Essas práticas encontram-se em fase inicial nos países em desenvolvimento (GUARNIERI et al., 2020). No Brasil, em 2010, foi instituída a Política Nacional de Resíduos Sólidos (PNRS), Lei no 12.305/2010, regulamentada pelo Decreto no 7.404/2010, que tem por objetivo a destinação final dos RSU ambientalmente adequada, priorizando a reutilização, a reciclagem, a compostagem, a recuperação e o aproveitamento energético, dentre outras [...] (Art. 3ํ, VII, da Lei 12.305/2010). E para inclusão socioprodutiva de Catadores/as foi sancionado o Decreto no 7.405/2010, que Institui o Programa Pró-Catador, que objetiva apoiar e dar incentivo às organizações de reciclagem, melhor as condições de trabalho, aumentar a inclusão social e econômica e ampliar a coleta seletiva e a reciclagem.

A PNRS/2010, no Capítulo II, inciso XI, definiu gestão integrada de resíduos sólidos como "[...] o conjunto de ações voltadas para solucionar o problema dos RSU, de forma a considerar as dimensões política, econômica, ambiental, cultural e social, com a premissa do desenvolvimento sustentável [...]", também instituiu instrumentos por meio dos quais a PNRS/2010 é implementada dentre eles o plano de gestão de resíduos (art. 8o), a serem elaborados a nível nacional, estadual, microrregional, de regiões metropolitanas ou aglomerações urbanas, intermunicipal, municipal, bem como os planos de gerenciamento (BRASIL, 2010).

A PNRS/2010 condicionou que os municípios elaborassem o PMGIRS para obterem acesso aos 
recursos da União, para ampliar e melhorar os serviços de limpeza urbana e o manejo dos RSU. Serão priorizados os municípios que optarem por planos de gestão regionais e planejamentos intermunicipais, incluída a elaboração e implementação de plano intermunicipal, bem como os que implantarem a coleta seletiva com a participação de cooperativas ou outras formas de associação de Catadores/as de materiais reutilizáveis e recicláveis formadas por pessoas físicas de baixa renda (BRASIL, 2010).

A Lei $n$ ㅇ 12.305/2010 doutrina sobre a disposição final ambientalmente adequada dos rejeitos, cuja meta do Plano Nacional de Resíduos Sólidos será a eliminação e recuperação de lixões associadas à inclusão social e à emancipação econômica de Catadoras e Catadores de materiais reutilizáveis e recicláveis (BRASIL, 2010, art. 54). A implementação do plano de gestão é uma etapa importante para o sucesso de uma política pública, pois é nesse momento que de fato o município, bem como o sistema político, a partir das decisões inicialmente tomadas e direcionadas da consecução de objetivos estabelecidos, entrega para a sociedade os serviços, garantindo-os aos direitos sociais abstratos na Lei e concretos na política pública (RUAS, 2009).

A contratação dos serviços de Catadores/as organizados/as em cooperativas para a operacionalização da coleta seletiva nos municípios é uma realidade brasileira, mesmo antes da Lei no 12.305/2010. As primeiras iniciativas de formação cooperativa/associação de Catadores/as são da década de 1990, as quais organizavam as propostas e ações voltadas à mobilização social e valorização dos trabalhadores da limpeza pública e parcerias com grupos de Catadores/as (DEMAJOROVIC et al., 2007).

A inclusão social e produtiva de Catadores/as de materiais recicláveis ocorre com a implementação de políticas públicas que promovem a organização desses trabalhadores, por meio da economia solidária e da autogestão, em associações/cooperativas de trabalho e sua integração à coleta seletiva pelas municipalidades (BESEN et al., 2014). Nos últimos anos, essas iniciativas têm sido cada vez mais objeto de pesquisas acadêmicas, como as de Baptista (2015), Besen et al. (2014), Castilhos et al. (2013), Galon et al. (2016), Jacobi (2006, 2011), Nobrega et al. (2019), Ribeiro et al. (2009), Santos (2018), Silva (2017) e Silveira (2019), bem como do setor público, como as do IPEA (2010, 2013 e 2020), e de estudos locais, como Sguarezi et al. (2009, 2011 e 2018) e Melo et al. (2019). No entanto, é necessário analisar as ações realizadas para a concretização da política pública, de modo a reconhecer como ocorreu o acesso a estes direitos por parte das Catadoras e dos Catadores, e identificar os principais avanços e desafios na implementação desta política pública levando em conta os processos de inclusão social na coleta seletiva.

Nesse contexto, o objetivo do estudo foi de identificar os limites e as possibilidades da PNRS/2010 no que diz respeito à coleta seletiva com a inclusão socioprodutiva de Catadores/as de materiais recicláveis nos municípios do Estado de Mato Grosso, à luz do modelo previsto na PNRS/2010. Sabatier et al. (1985) e Sabatier (1986) doutrinam que algumas condições são necessárias para que a política pública tenha sucesso em sua implementação, dentre elas as que referem à decisão política, como: objetivos claros e consistentes, processo de implementação legalmente estruturado para melhorar a conformidade; e as que ocorrem durante o processo de implementação: os líderes da agência implementadora devem possuir habilidades gerenciais e políticas suficientes e devem ser comprometidos com os objetivos definidos em 
Lei; e o programa é ativamente apoiado por grupos organizados da sociedade e por alguns parlamentareschave durante o processo de implementação, com o judiciário sendo neutro ou simpático ao plano.

A implementação da política pública compreende as atividades efetuadas por indivíduos, grupos políticos ou privados com vista ao atendimento de objetivos previamente estabelecidos, abrangendo tanto esforços momentâneos para traduzir as decisões em propostas operacionais, como os esforços prolongados para realizar as mudanças determinadas por tais políticas (VAN METERet al., 2000). Essas políticas podem ter formas de importantes decisões administrativas (SABATIER et al., 1983). Só então é que se devem tomar novas decisões, buscar novas alternativas e inovar ideias adaptando a política pública à realidade local com melhorias aos cidadãos (DOWBOR et al., 2018).

No Estado de Mato Grosso, as políticas públicas municipais de RSU são subordinadas à Lei Federal no 12.305/2010 e à Lei no 7.862/2002 - Política Estadual de Resíduos Sólidos, a de Mato Grosso (PERSMT), alterada pela Lei Estadual no 7.806 de 19 de dezembro de 2009, ou seja, os planos municipais, até o momento, são orientados por políticas na esfera estadual anteriores à aprovação da PNRS/2010. Só em 2020 que o Estado de Mato Grosso, pela Secretaria de Estado de Meio Ambiente (SEMA), iniciou a construção do Plano Estadual de Resíduos Sólidos (PERS). E essa construção ainda é muito instrumental e com pouca participação, de Catadores/as por exemplo. Na visão instrumentalista, a política pública perde parte de seu poder, pois decisões são tomadas anteriormente (SOUZA, 2006). E por não contemplar no processo de construção uma categoria que trabalha diretamente com a gestão de RSU, na Coleta seletiva, os/as Catadores/as de Materiais Recicláveis.

Outra dificuldade é a falta da continuidade das ações por dentro do pacto federativo. No caso da PNRS, é obrigação legal dos estados implementarem as políticas. Porém o que se percebe no caso de Mato Grosso é um descaso com a PNRS, visto que se passaram dez anos e o estado ainda não se organizou nesse sentido. Apesar disso, cada município da federação pode e deve definir em seu território local uma Política Municipal de resíduos sólidos, conforme limitado pela Carta Maior de 1988. Segundo a Lei no 12.305/2010, a gestão dos resíduos no âmbito local deve ser feita por meio do PMGIRS, englobando desde a origem, o volume, a caracterização e as formas de destinação e disposição final adequadas, bem como a previsão de metas de não geração, redução, reutilização, coleta seletiva, entre outras diretrizes consagradas.

Da mesma forma, as ações do Programa Pró-Catador MT, convenio MTE/SENAES № 00010/2013 SICONV aprovado sob no 782379/2013, com validade de 2013 a 2018, no valor de $\mathrm{R} \$ 3.750 .000$,00, dos quais $\mathrm{R} \$ 3.562 .500,00$ correspondem ao repasse do MTE e $\mathrm{R} \$ 187.500,00$ aportados pelo convenente a título de contrapartida, conforme termo de convênio. Esse valor, inicialmente previsto, voltado a diagnosticar a realidade dos catadores e promover a inclusão socioprodutiva, por meio do planejamento e execução de ações para a criação de empreendimentos econômicos solidários, fortalecimento das organizações e rede de cooperação de resíduos sólidos nos municípios de abrangência do projeto, oportunizando a melhoria de condições de vida, trabalho, renda e acesso a políticas públicas do Estado de Mato Grosso. No entanto, o programa foi iniciado e não conseguiu atingir os objetivos e cumprir a maior parte das metas estabelecidas.

Dados da prestação de contas, relatório emitido em 20/06/2020, em mostra que: Houve 
desembolso de apenas $R \$ 1.428 .720,00$, dos quais foram utilizados $R \$ 238.491,25$. E, em 27/08/2018, foram restituídas às contas do Concedente e Convenente, pela proporcionalidade calculada pela Plataforma +Brasil, o montante de R\$ 1.705.627,84, conforme aba "Saldo Remanescente OBTV", disponível em Prestação de Contas, na Plataforma +Brasil. De acordo com o relatório, a SEMA, responsável para gerir o projeto, alega que houve dificuldades, principalmente para contratação de empresa especializada na elaboração do diagnóstico da situação dos catadores de materiais recicláveis, dessa forma, houve o corte de recursos orçamentários por parte da SENAES.

\section{METODOLOGIA}

Trata-se de uma pesquisa qualitativa, descritiva. Os dados primários foram obtidos com base numa pesquisa de campo, e os secundários, por meio de pesquisa documental, com base em Minayo (1994) e Richardson (1985). Para o fechamento da investigação foi utilizada a análise de conteúdo, conforme Bardin (2009). A pesquisa documental e os dados secundários foram acessados por meio da análise de diferentes documentos: na esfera nacional, na esfera estadual, Política e Plano Estadual de Resíduos Sólidos do Estado de Mato Grosso; nas esferas municipais foram acessados o Plano de Gestão Integrada de Resíduos Sólidos (PMGIRS), a Política Pública de Economia Solidária e os Planos de Saneamento Básicos; junto às cooperativas e associações foram acessadas as atas dos empreendimentos, documentos e relatórios internos, histórico e produções acadêmicas relevantes relativas ao objeto da investigação; houve participação nas reuniões do Fórum Mato-Grossense de Lixo e Cidadania (FMTL\&C); e pesquisa às demais leis disponíveis no portal ${ }^{1}$.

A pesquisa de campo permitiu o acesso aos dados primários. A mesma ocorreu no ano de 2020 e versou sobre o PMGIRS e a inclusão socioprodutiva de Catadores/as na prestação do serviço de coleta seletiva. Os dados foram obtidos por meio de visitas in loco para observação e pela realização de entrevista em profundidade. Essa etapa permitiu a imersão do pesquisador no ambiente de pesquisa, visando à descoberta de significado e à importância dos fenômenos sociais para as pessoas envolvidas. A entrevista se deu por um roteiro de perguntas direcionadas e previamente estruturadas, de modo impessoal, realizada com doze atores que atuam diretamente na política pública. Para a análise de conteúdo foram realizados os procedimentos: transcrição completa das entrevistas; pré-análise do conteúdo; agrupamento das entrevistas; definição das categorias de análise de acordo com os objetivos da pesquisa e de roteiro de entrevista; e interpretação dos dados a partir do quadro analítico (BARDIN, 2009). Os atores participantes da pesquisa são operadores da política pública, sendo: representante da Gestão Pública (GP); Ministério Público (MP); representante da Economia Solidária (Ecosol); representante da Associação e Cooperativa de Catadores/as (Cat), Sociedade Civil (SC) e representantes do Fórum Mato-Grossense de Lixo e Cidadania (FMTL\&C). Todas as falas foram gravadas e transcritas, empregando-se a técnica de análise de conteúdo de dados.

O estudo compreendeu quatro municípios do Estado de Mato Grosso: Colíder, Cuiabá, Rondonópolis e Tangará da Serra, de modo intencional, primeiro, por estarem dispostos em quatro 
diferentes mesorregiões mato-grossenses, segundo, por terem finalizado o PMGIRS; implementado a Política Pública de Economia Solidária; implementado a coleta seletiva; e possuir grupos de Catadores/as de materiais recicláveis organizados em cooperativas ou associações atuando na coleta seletiva. Tais características permitiram analisar o processo de aplicação da PNRS, Lei no $12.305 / 10$, e seus reflexos no exercício profissional de Catadores/as de materiais recicláveis, em diferentes contextos.

\section{RESULTADOS E DISCUSSÃO}

Os resultados da pesquisa realizada nos municípios mato-grossenses compreendem o levantamento do histórico e os aspectos e ações institucionais da coleta seletiva e do PMGIRS e em relação à inclusão socioprodutiva e o seu diálogo com a PNRS/2010. Busca mostrar e compreender como foi se organizando a política nos municípios.

\section{A coleta seletiva em Colíder, MT: perspectivas históricas institucionais}

O Município de Colíder localiza-se a 647 quilômetros da capital, Cuiabá, sendo habitado por 33.649 pessoas, conforme estimativa do IBGE (2020). Está a 324 metros de altitude em relação ao nível do mar, e é parte da mesorregião norte mato-grossense, bioma Amazônia, importante região, tanto pela floresta quanto pelas suas nascentes. Esse município é partícipe da bacia hidrográfica do Rio Carapá, constitui uma importante rede de drenagem, que drena também o vizinho Nova Canaã do Norte, sendo contribuinte da bacia do Rio Teles Pires, que está inserida na bacia do Rio Amazonas (IBGE, 2020).

O município de Colíder se antecipou na PNRS/2010 no que se refere à coleta seletiva com a inclusão socioprodutiva de Catadores/as devido aos problemas socioambientais que vinham ocorrendo. 0 órgão responsável pela gestão dos resíduos é a Prefeitura municipal. Desde 1983 até 2008, o município lançava seus RSU no lixão a céu aberto localizado próximo ao Rio Carapá, que fornece água para o abastecimento da cidade. De acordo com o Gestor Público, "[...] o lixão era acima da captação de água, e em 2005 foi constatado que as águas do rio estavam sendo contaminadas pelo chorume e poluentes provenientes do lixão, podendo causar impactos ambientais e riscos para a saúde". Outro fator destacado pelo gestor é que "no lixão havia famílias que trabalhavam em circunstância insalubre".

A sociedade civil iniciou uma discussão, desencadeou um processo de mobilização de uma rede de atores que passou a intervir e discutir solução política com prioridade junto aos órgãos governamentais, conforme narrativa de um ator da sociedade civil: "[...] há anos as instituições de educação debatiam e apontavam para a sociedade e para o poder público a importância da reciclagem para a geração de renda e para o meio ambiente" (SC).

A elaboração de plano e disposição adequada dos resíduos estavam previstas na Lei Orgânica no 1, de 05 de abril de 1990, de Colíder, ou seja, o município já percebia a necessidade de solucionar os problemas de RSU e previa uma solução no art. 50: "O Município, conjuntamente com o Estado, estabelecerá planos e programas para coleta, transporte, tratamento e destinação final de resíduos sólidos, urbanos e industriais, com ênfase nos processos que envolvam sua reciclagem" (COLIDER, 1990). A trajetória de ações voltadas à gestão de RSU no município pode ser destacada na Figura 1. 


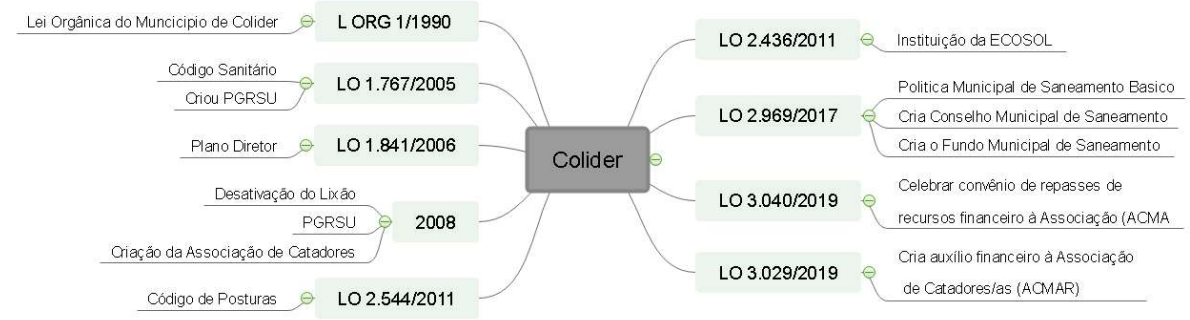

Figura 1: Linha do tempo com os principais marcos legais de Colíder, MT

O PMGIRS e a coleta seletiva com inclusão de Catadores/as estavam presentes na Lei Orgânica, apesar disso, foi necessário que a sociedade se mobilizasse para concretizar a implementação.

A prioridade foi resolver o problema da contaminação da água do rio pelo chorume do lixão. Foi uma questão de saúde pública, pois municípios que não apresentam esse problema vão empurrando para outro gestor, e assim vai passando [...]. Foi realizado um seminário sobre desenvolvimento, e entre os pontos mais discutidos estava a questão dos resíduos, destacando-se a coleta precária e o lixão próximo da cidade com risco de contaminação do manancial de abastecimento público de água [...] (GP).

Houve mobilização da sociedade civil e apoio da Secretaria de Meio Ambiente (SEMA), que resultou em uma Ação Cível Pública (ACP) junto à Promotoria de Justiça da Comarca de Colíder contra a Prefeitura Municipal por danos causados à saúde pública e ao meio ambiente, devido ingerência na gestão dos RSU e disposição final de forma inadequada, o que obrigou o município a apresentar e executar o projeto de coleta dos RSU, a dar destino adequado e executar projetos de educação ambiental (DUARTE, 2014; PEREIRA, 2014)

A articulação política entre os atores políticos do Executivo Municipal e atores especialistas oriundos da comunidade epistêmica e da sociedade civil atuou no sentido de providenciar o fechamento do lixão e na implantação do aterro sanitário, elaborou propostas que contemplavam os interesses e a organização de Catadores/as. Em 2005, foi iniciado um Plano de Gerenciamento de RSU, respaldado pelo Plano Diretor, instituído pela Lei no 1.841/2006. Uma das diretrizes contidas no art. 20 é a elaboração e implementação de Programa de Gerenciamento dos Resíduos Sólidos visando à reciclagem.

Para formulação e implementação do PMGIRS, algumas preocupações estratégicas foram citadas pelos entrevistados: "a coleta regular do resíduos, o lixão e a existência de Catadores/as no lixão" (GP); "preocupações socioambientais" (GP; Cat; SC); "funcionar a coleta seletiva” (Cat; GP; SC); “com Catadores/as que estavam no lixão, por estarem trabalhando expostos em local insalubre e com riscos à saúde" (SC); "resolver um problema de décadas, que era o lixão a céu aberto e que naquela oportunidade os/as Catadores/as estavam expostos/as às condições sanitárias de risco" (SC).

As prioridades elencadas pelos gestores foram: "construção do aterro sanitário, desativação do lixão, organização da coleta regular e organização de Catadores/as organizados/as", que também podem ser contempladas nas narrativas de atores da Sociedade Civil e da representante da Economia Solidária:

[...] a primeira questão estratégica foi a de resolver um problema socioambiental de décadas. Posteriormente a isso, trabalhar a educação ambiental de forma ampla com a população, preparando para o novo processo de coleta que incluía aí a separação doméstica dos resíduos, também trabalhando a importância da reciclagem como forma de gerar trabalho e renda para os/as Catadores/as (SC).

Desde 2001, havia notificação e determinação do Ministério Público para a retirada dos/as 
Catadores/as do lixão, em virtude de uma matéria que mostrava as pessoas morando e se alimentando das sobras, e nada havia sido feito. No processo de discussão e implantação do aterro sanitário já havia contido a necessidade de uma transição dos trabalhadores, com a implantação do aterro houve várias frentes que abordavam a nova realidade, uma delas era a situação dos/as Catadores/as [...]". O lixão tinha muitos/as Catadores/as, quando foi fechar houve um chamamento pelos órgãos gestores, tanto de Catadores/as do lixão quanto dos que catavam dispersos nas ruas. Foram feitas campanhas em um período chamando esses/as Catadores/as para inserção em EES, todos foram oportunizados (Ecosol).

Os fatores que contribuíram para a implementação do PMGIRS foram elencados por todos os participantes da pesquisa: fatores sociais, econômicos, ambientais, políticos e vontade dos gestores, bem como a sensibilização da população à importância da inclusão social. Alguns setores participaram das discussões: Câmara de vereadores, Fórum Municipal Lixo e Cidadania, Secretarias de Saúde, do Meio Ambiente, de Infraestrutura, de Desenvolvimento Econômico e Saneamento, Educação (escolas, UNEMAT, UFMT), representante da Economia Solidária, técnicos do município, engenheira sanitarista, APAE, Clubes de Serviços, Ministério Público, representantes do comércio e da indústria e a mídia, que, segundo relatos, fez parte tanto das discussões de orientação à população, na separação dos resíduos recicláveis e na educação ambiental para implantar a coleta seletiva. Tiveram destaque os gestores e técnicos do município, conforme depoimento do Gestor Público: “[...] na verdade, nós tínhamos um gestor que era bastante empreendedor [...], partiu dele e sua equipe técnica, que buscaram os recursos do Estado para a execução do Plano" (GP). Nesse sentido, Kingdon (2014) explica que os empreendedores políticos (policy entrepreneurs) são aquelas pessoas que têm disposição de investir seu tempo, energia, reputação, recurso, em ideias que possam trazer-Ihes futuros benefícios.

A Prefeitura, em parceria com o SICRED, construiu a Usina de Triagem em 2008, com equipamentos necessários para o trabalho de triagem. A consolidação da coleta seletiva ocorreu em 2009, após negociação com os/as Catadores/as para inseri-los em associação. Para sua organização, tiveram apoio e treinamento de grupos de Universidades, da Economia Solidária e do Fórum Municipal Lixo e Cidadania. Foram capacitados para a autogestão da associação, no que tange à saúde ocupacional e ambiental, à segurança patrimonial e do trabalho, à gestão financeira e de mercado. A formação desses trabalhadores e as parcerias firmadas junto ao poder público, por meio de contrato de prestação de serviços para a Prefeitura, proporcionaram igualdade na remuneração, melhora da qualidade de serviços e aumento da quantidade de materiais recicláveis. Foi firmado um acordo financeiro entre a Prefeitura e a Associação, em que a Prefeitura repassa vinte e cinco mil reais por ano para pagar as despesas da Usina de Triagem, como água, energia e material de limpeza. A coleta seletiva é de $100 \%$ no município e vai para a Usina de Triagem (UT) para separação pelos/as Catadores/as. A Associação de Catadores/as de Materiais Recicláveis (ACMAR) conta com 22 membros que, juntos, fazem a triagem e comercializam cerca de 60 toneladas por mês, no entanto, o município não firmou contrato com a Associação para operacionalizar a coleta seletiva.

\section{A coleta seletiva em Cuiabá MT: perspectivas históricas institucionais}

Cuiabá é a capital e o maior município do Estado de Mato Grosso em termos populacionais, com 618.124 habitantes, conforme estimativa do IBGE (2020). A altitude média é de 165 metros acima do nível 
do mar. Pertence à mesorregião Centro-Sul mato-grossense e está cercado por três grandes biomas: 0 Amazônico, o Cerrado e o Pantanal, além de estar no sopé de Chapada dos Guimarães (uma das sete chapadas do Brasil). É considerado porta de entrada da Floresta Amazônica, porém a vegetação do município é a do cerrado, desde suas variantes mais arbustivas até as matas mais densas à beira dos cursos (CUIABÁ, 2009).

Em Cuiabá, a organização de Catadores/as data de 1993, com a formação da Associação dos Catadores de Materiais Reaproveitáveis e Recicláveis do Lixão de Cuiabá. Em 1994, essa associação foi transformada em cooperativa, passando a ser denominada de Cooperativa dos Trabalhadores de Produtores e Recicladores de Materiais Recicláveis de Mato Grosso (COOPERMAR). Em 1996, os/as Catadores/as passam a trabalhar na Usina de Reciclagem implantada no Aterro Sanitário de Cuiabá.

No entanto, em Cuiabá, ao longo dos anos, a coleta seletiva sofreu avanços e retrocessos, do mesmo modo que a inclusão socioprodutiva de Catadores/as de materiais recicláveis no município, o que pode ser verificado na linha do tempo, com os principais marcos legais de Cuiabá, MT (Figura 2).

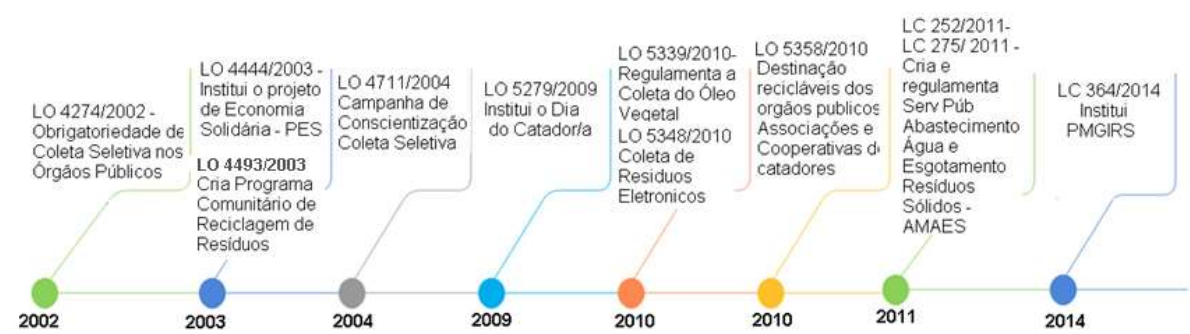

Figura 2: Linha do tempo com os principais marcos legais de Cuiabá, MT

No que se refere a ações da coleta seletiva, a Lei no 4.274, de 22 de outubro de 2002, tornou obrigatório aos órgãos públicos municipais realizar a coleta seletiva dos seus resíduos, de modo a permitir sua posterior reciclagem. Ao mesmo tempo, vinha tramitando a Lei $n=4.444 / 2003$, que instituiu o projeto de Economia Solidária, tendo por objetivos potencializar o desenvolvimento de atividades de grupos organizados e de baixa renda, de forma a integrá-los no mercado formal, e tornar suas atividades autossustentáveis. Isso fortaleceu a formulação da Lei no 4.493, aprovada em 2003, criando o Programa Comunitário de Reciclagem de Resíduos, que dispõe que todas as Secretarias Municipais terão que implantar em suas respectivas áreas de atuação o Programa Comunitário de Reciclagem de Resíduos Orgânicos e Inorgânicos no âmbito do município de Cuiabá (CUIABÁ, 2002, 2003).

Para operacionalizar a coleta seletiva e desenvolver educação ambiental, em 2004 foi instituída uma campanha de esclarecimento à população, referente aos malefícios que o acúmulo de resíduos pode causar, cujo objetivo era a redução da utilização dos aterros sanitários, pois a reciclagem de papéis, vidros, plásticos e metais representava $40 \%$ do resíduo doméstico. Para reconhecimento e valorização do trabalho dos/as Catadores/as, foi instituída a Lei no 5.279/2009, que fixou no calendário oficial de Cuiabá o dia 10 de dezembro como o dia dos Catadores de resíduos, como data para reverenciar tais atores pelo trabalho que desempenham, como indispensáveis à preservação do meio ambiente, na condição de importantes Agentes, Defensores do Meio Ambiente (CUIABÁ, 2009).

Em 2010, foi regulamentada a coleta de óleo de cozinha, responsabilizando as empresas que fazem 
refeições pelo acondicionamento em containers e gerenciados por Organizações Não Governamentais, associações de Catadores/as e cooperativas [...], conforme a Lei № 5.593/2010, também a obrigatoriedade de descarte ambientalmente adequado aos resíduos tecnológicos, Lei no 5.348/2010 (CUIABÁ, 2010).

Em Cuiabá, no que se refere à inclusão social de Catadores/as de materiais recicláveis, o processo foi protagonizado pelos/as Catadores/as por meio do FMTL\&C e Ministério Público do Estado de Mato Grosso, além do Ministério Público do Trabalho (MPT), desde meados de 2012, o que resultou na construção de uma proposta de Programa de Gerenciamento de Resíduos com a finalidade de organizar o serviço público de coleta seletiva de resíduos secos domiciliares, nos termos definidos pela legislação federal, com a inserção de Catadores/as, por meio de suas cooperativas e associações. Em outubro de 2012, a Prefeitura de Cuiabá, por intermédio da Secretaria Municipal de Serviços Urbanos, lançou o projeto "Cuiabá Recicla", em parceria com o Instituto Coca-Cola, com a Cooperativa dos Trabalhadores de Materiais Recicláveis (COOPEMAR), com a ONG "Doe Seu Lixo", do Rio de Janeiro, com o Grupo Renosa e com o Centro de Referência Valorizando Vidas. Na ocasião, também foi inaugurada a Usina de Reciclagem de Triagem (URT), cujos objetivos foram: favorecer a inclusão socioprodutiva de Catadores/as por meio da promoção de emprego e renda; melhorar as condições de vida de Catadores/as e de suas famílias; e reduzir a quantidade de RSU encaminhados ao aterro sanitário.

O PMGIRS de Cuiabá foi instituído pela Lei Complementar no 364, de 26 de dezembro de 2014, pautada nos princípios e diretrizes constantes nas Leis no 11.445/07 e 12.305/10 (BRASIL, 2007, 2010). Foi incorporada ao projeto de lei a obrigatoriedade de separação dos resíduos gerados em condomínios residenciais, comerciais e industriais, definida pela Lei municipal 4.390/2003, alterada pela lei 5.272/09, com reformulação da redação da Lei 5.422/2011. Dentre os objetivos da lei estavam: integrar Catadores/as de materiais reutilizáveis e recicláveis nas ações que envolvam a responsabilidade compartilhada, pelo ciclo de vida dos produtos (art. 6으, XII); em relação aos instrumentos econômicos, a lei poderá instituir medidas indutoras e linhas de financiamento para atender, prioritariamente, às iniciativas de [...] implantação de infraestrutura física e aquisição de equipamentos para cooperativas/associação de Catadores/as de materiais reutilizáveis e recicláveis formadas por pessoas físicas de baixa renda; e estruturação de sistemas de coleta seletiva e formas de participação da logística reversa no âmbito local (art. 7o, III; IV).

As preocupações estratégicas relevantes na fase de elaboração do PMGIRS destacaram: "a inclusão socioprodutiva de Catadores/as de materiais recicláveis dentro do PMGIRS, a coleta seletiva, a destinação correta dos rejeitos" (PG; FMTL\&C); “a contaminação ambiental” (GP); "a participação de Catadores/as no plano" (GP); e "sensibilizar o legislador para resguardar os/as Catadores/as no processo" (MP). Para o FMTL\&C, "essa atenção se intensificou uma vez que esses indivíduos foram vistos trabalhando de forma indigna nos lixões, e por eles serem minoria". Para o Gestor Público, "os/as Catadores/as estavam vivendo no lixão e dos resíduos, com a presença de crianças nas frentes de trabalho de catação". A Defensora Pública complementa que quando houve mortes de crianças e adultos, registradas e divulgadas pelos meios de comunicação, começou a necessidade de atender a obrigatoriedade judicial (MP).

Na opinião dos entrevistados também ocorreram alguns fatores políticos, sociais e econômicos que influenciaram a inclusão social na PMGIRS: os/as Catadores/as se mobilizaram, politizaram e reivindicaram 
seus direitos perante a classe política, por serem estes mão-de-obra barata para os atravessadores que ganhavam com as indústrias (GP; FMTL\&C, Cat.).

A proposta da inclusão socioprodutiva de Catadores/as foi discutida com os representantes do segmento e encaminhada para aprovação do Legislativo local. No entanto, a lentidão por parte do município em gerar soluções que minimizem a exclusão social dos trabalhadores de recicláveis tem corroborado em afirmar a dificuldade em gerar e implementar políticas públicas consistentes que, de fato, possam alcançar os propósitos para os quais foram idealizadas. Essa realidade pode ser observada a respeito da descontinuidade do lixão, que, em Cuiabá, não ocorreu de fato, mesmo com a Política Municipal de Gestão Integrada de Resíduos Sólidos instituída pela Lei Complementar no 364, de 26 de dezembro de 2014.

O aterro controlado de Cuiabá recebe cerca de 600 toneladas de resíduos diariamente, inclusive do Rio Cuiabá, por meio das balsas ecológicas. Cerca de $2 \%$ são destinados para coleta seletiva para quatro cooperativas de Catadores/as que estão organizados/as e não recebem pelo trabalho realizado. Cerca de 300 trabalhadores vivem de forma irregular e sobrevivem economicamente do processo de catação desses resíduos dentro e no entorno do aterro, dessa forma, o município passou a acompanhá-los para o encerramento do aterro controlado, que deverá, segundo a lei, ser descontinuado até 2021.

Quanto aos avanços que representam e as parcerias entre governos municipais e cooperativas de Catadores/as de materiais recicláveis, o poder público municipal dividiu Cuiabá em quatro partes para atender as quatro organizações responsáveis pela coleta seletiva, ACAMARC, COOPERMAR, COOPERUNIÃO E COOREPAN. As organizações atendem basicamente os grandes geradores. O faturamento anual das cooperativas em 2020 foi de R\$ 641.595,59 (ANUÁRIO DA RECICLAGEM, 2020).

Não se pode falar de uma grande participação da sociedade para equacionar o problema do lixão da cidade, nem para discutir o PMGIRS, mas alguns atores se mobilizaram para buscar soluções: ACAMARC - Associação de Catadores/as de Materiais Recicláveis; SEDRAF - Secretaria de Estado de Desenvolvimento Rural de Mato Grosso; COOREPAM - Cooperativa Alternativa de Materiais Recicláveis; Secretaria de Educação Municipal; SINDUSCON - Sindicato da Indústria da Construção; AMM - Associação MatoGrossense dos Municípios; SMSU - Secretaria Municipal de Serviços Urbanos; SMAAF - Secretaria Municipal de Meio Ambiente; SEMA - Secretaria Estadual do Meio Ambiente; O. L. Dias Neto Minhocultura Estrela Maior; COOPERMAR - Cooperativa dos Trabalhadores da Reciclagem do Estado de Mato Grosso; OAB - Ordem dos Advogados do Brasil; Instituto Mato-Grossense de Direito e Educação Ambiental; Coordenadoria de Vigilância Sanitária - SMS/CUIABÁ; Departamento de Serviço Social - UFMT; Departamento de Geografia - UFMT; Engenheiras Sanitaristas e colaboradores da sociedade civil.

Mesmo com essas discussões a inclusão socioprodutiva de Catadores/as não avançou. De acordo com a representante da COOREPAM, havia um contrato firmado entre a Prefeitura de Cuiabá e as Cooperativas para fazerem a coleta nos grandes empreendimentos, no entanto, o município não cumpriu o contrato e não está pagando as cooperativas. Isso mostra a falta de compromisso com esses empreendimentos. 


\section{A coleta seletiva em Rondonópolis MT: perspectivas históricas institucionais}

Rondonópolis está localizado na região Sudeste do Estado de Mato Grosso, com seu Bioma Cerrado e com população de 236.042 habitantes, conforme estimativa do IBGE (2020). Tem o segundo maior PIB do estado e localiza-se estrategicamente no entroncamento das Rodovias BR 163 e BR 364, que liga as regiões Norte e Sul do país, por onde são transportadas as produções agrícola e industrial para os grandes centros metropolitanos e portos do Brasil. Seu processo de urbanização até a década de 1960 foi lento, não contínuo e linear, retomando o crescimento substancial principalmente a partir da década de 1980, associado às sucessões socioeconômicas e territorialidades que se cristalizaram no espaço, principalmente pela urbanidade (DEMAMANN, 2011). Assim como em outros municípios do Brasil, a geração de RSU com o crescimento da urbanização traz problemas sociais e ambientais.

A partir da primeira década de 2000, a Prefeitura de Rondonópolis iniciou diversas ações relacionadas à gestão dos resíduos gerados no município (Figura 3).

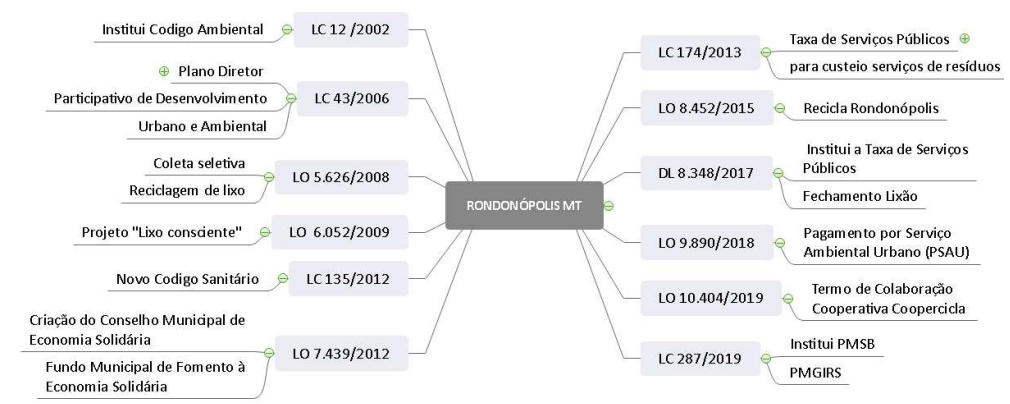

Figura 3: Linha do tempo com os principais marcos legais de Rondonópolis, MT

A coleta seletiva estava prevista no código ambiental de Rondonópolis, Lei Complementar no 12/2002, que traz o texto: “O município deverá implantar adequado sistema de coleta, tratamento e destinação dos resíduos sólidos urbanos [...], incentivando a coleta seletiva, segregação, reciclagem, compostagem e outras técnicas que promovam a redução do volume total dos resíduos sólidos gerados" (art. 87). O Plano Diretor, Lei Complementar no 43/2006, em seu artigo 32, propõe que o município deverá incentivar, por meio de programa, a implantação de reciclagem de resíduos, podendo, para tal fim: oferecer como vantagem o seu produto, resultante da coleta seletiva; incentivos fiscais; e incentivar a formação de cooperativas de Catadores/as de materiais recicláveis.

No ano de 2008, foi aprovada a Lei Ordinária no 5.626/2008, que dispõe sobre a coleta seletiva e reciclagem dos resíduos no município, consolidando-se lentamente. Em 2015, foi criado o Programa Recicla Rondonópolis, que dispõe, no art. 7ํ, § 3ㅇ: “caberá ao município dar a destinação final correta dos resíduos recicláveis, iniciando o processo através da coleta seletiva dos resíduos recicláveis, prioritariamente mediante contratação de associação ou cooperativas de Catadores/as de materiais recicláveis" (RONDONÓPOLIS, 2008).

Quanto à disposição final dos resíduos gerados, o lixão existia desde 1980, com aproximadamente 45 trabalhadores autônomos que dependiam da coleta de resíduos recicláveis como sustento familiar. De acordo com o Gestor Público, “em 2017, na construção do PMGIRS e fechamento do lixão, foi construído o aterro sanitário por meio de um contrato junto à autarquia Serviço de Saneamento de Rondonópolis 
(SANEAR) e uma empresa privada gerenciadora do aterro". No aterro, foi construída uma Usina de Triagem para o trabalho dos/as Catadores/as.

Na opinião do Gestor Público, alguns fatores influenciaram a estruturação da Política de Resíduos Sólidos com inclusão de Catadores/as. Fator legal: “devido à exigência da Lei Federal 12.305/2010 e à cobrança do Ministério Público"; também foram indicados fatores políticos e sociais, "[...] o ente municipal não consegue fazer ação sem prestar contas à sociedade, e nessa questão da inclusão social de Catadores/as, [...] a partir do momento que o município fosse fechar o lixão, a própria sociedade iria cobrar a inclusão dessas famílias" (GP); e complementa, "[...] O município sempre teve um olhar para os/as Catadores/as, para essa política de inclusão social, principalmente no período do Partido dos Trabalhadores no Governo Federal, especificamente, pois, para o acesso a recursos federais, temos de ter a política de inclusão social” (GP).

As pessoas moravam praticamente dentro do lixão, em condições subumanas, sem dignidade nenhuma. 0 fechamento do lixão foi dia 1 o de setembro de 2017, seguido da criação da Cooperativa Nova Esperança, no dia 4 de setembro, com os Catadores. Eles tiveram um local adequado para trabalhar, com os equipamentos de segurança necessários, uniformes e toda a assistência e apoio que precisam, e são remunerados pela prestação de serviços ambientais, como forma de beneficiá-los devido à situação de vulnerabilidade socioeconômica, e dessa forma materializar a contrapartida do serviço que está sendo prestado (MP).

A respeito dessa narrativa, Galon et al. (2016) sustentam que, embora esses trabalhadores contribuam para o meio ambiente e para o mercado de reciclagem, trabalham em ambiente insalubre, elevado grau de periculosidade, grandes riscos de acidentes de trabalho ou adoecimento, com baixa renda e sem reconhecimento por parte da sociedade.

Para os gestores públicos, as audiências públicas, a vontade política e a constante atividade de educação ambiental em escolas, empresas e no poder público, não podem faltar na implementação da coleta seletiva.

O poder municipal, inicialmente inerte, passou a ser influenciado pelos avanços da legislação ambiental e provocado pela sociedade civil local a buscar alternativas para o problema do lixão. Foram realizadas ações junto à comunidade voltadas à inclusão de Catadores/as que atuavam informalmente na cidade. Essas ações envolveram vários segmentos da sociedade, criando-se um comitê específico para tratar dos/as Catadores/as, liderados pelo Ministério Público e SANEAR. No sentido de sensibilizar as pessoas sobre a importância da reciclagem e a maneira correta de fazê-la, a Promotoria de Justiça Cível Curadoria da Cidadania, Consumidor e Meio Ambiente coordenou uma campanha junto à população, que contou com apoio de 2.300 jovens e 48 Catadores/as de materiais recicláveis. Alguns atores atuaram para a implementação da coleta seletiva no município:

Todos deram um apoio, mas para mim são as entidades, e foram todas. Secretaria de Meio Ambiente, Secretaria de Assistência Social, Ministério Público do Estado, Ministério do Trabalho, Igreja, Juizado Volante Ambiental (JUVAM), diretores e técnicos do SANEAR, promotor de Justiça, a procuradora do Trabalho, a secretária municipal de Promoção e Assistência Social, o procurador geral, o secretário municipal do Meio Ambiente, bem como representantes do Projeto Rede, das Secretarias Municipais de Habitação e Urbanismo, de Promoção e Assistência Social e de Saúde e da empresa que será responsável pelo aterro sanitário, entre outros (GP). 
Em 2019, foram elaborados os planos de Saneamento Básico e o PMGIRS, que, segundo o Gestor Público, a demora se deu pela complexidade do Plano e falta de vontade política.

O Plano em si é uma complexidade para fazer o levantamento de informações, a questão da participação social que também, a meu ver, é muito importante... e infelizmente caiu de uma gestão para outra, enfim. Só conseguimos fazer o plano mesmo agora (GP).

Em Rondonópolis, a coleta seletiva ocorre em torno de $40 \%$ da cidade em 2020. Contudo, indicava, também, a existência de avanços ao longo dos anos, a exemplo da ampliação do número de áreas atendidas. Esses avanços foram possíveis devido o município ter firmado contrato de serviços com uma associação e uma cooperativa de Catadores/as de materiais recicláveis. Mesmo com os avanços da gestão de resíduos na cidade, segundo os gestores, para implantar 100\% da coleta seletiva são necessários recursos financeiros, melhora na educação ambiental sensibilizando os munícipes no comprometimento de suas obrigações e, principalmente, ampliação do número de organizações de Catadores/as de modo a atender a demanda de recicláveis do município.

\section{A coleta seletiva em Tangará da Serra - MT: perspectivas históricas institucionais}

Tangará da Serra está a 241 quilômetros da capital, Cuiabá, e é o quinto maior município do Estado de Mato Grosso em termos populacionais, com 105.711 habitantes, conforme estimativa do IBGE (2020). A altitude média é de 423 metros acima do nível do mar. Pertence à mesorregião Sudoeste mato-grossense, onde parte do município é partícipe do bioma cerrado e outra parte da floresta. Ou seja, encontra-se numa área de transição entre cerrado e floresta. Ao mesmo tempo, está na cabeceira do Pantanal, entre as Serras de Tapirapuã e de Parecis, divisor da bacia de águas entre a Bacia Amazônica e a Bacia do Prata (ANDRADE, 2009; KRINSKI et al., 2009).

Antes da aprovação da PNRS/2010, Tangará da Serra foi a primeira cidade do Estado de Mato Grosso a implantar e executar regularmente a coleta seletiva de materiais recicláveis, ainda em 2005, quando criou o Programa Tangará Recicla (MELO et al., 2019). A trajetória de ações desenvolvidas referente à política de resíduos sólidos no município pode ser destacada na Figura 4.

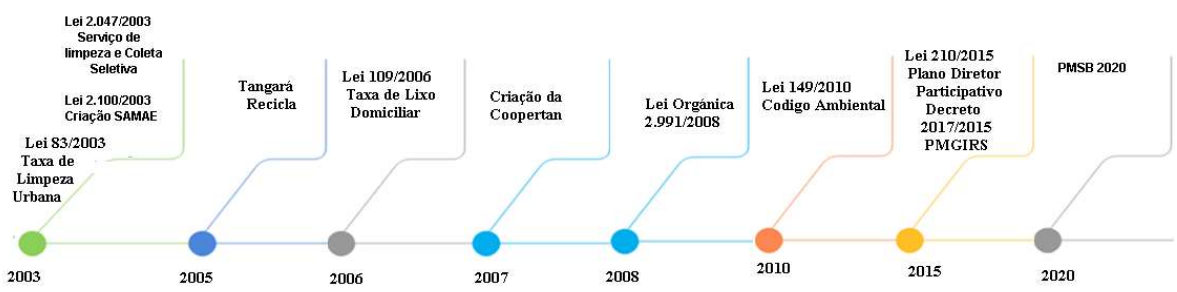

Figura 4: Linha do tempo da Política de Gestão de Resíduos Sólidos do Município de Tangará da Serra, MT

No início do ano de 2003, foi instituída a Lei no $80 / 2003$, que dispõe sobre a taxa do resíduo urbano, mas não incluiu a coleta seletiva. O serviço de limpeza urbana no município foi regulamentado pela Lei no 2.047/2003 e estabeleceu aos usuários que acondicionassem apropriadamente o material reciclável, bem como material orgânico separado do resíduo convencional, visando à coleta seletiva. No mesmo ano, foi criada a Autarquia do Serviço Autônomo Municipal de Água e Esgoto (SAMAE) - Lei no 2.100/2003. Dentre as competências e atribuições da autarquia está o gerenciamento integrado de resíduos sólidos. 
(TANGARÁ DA SERRA, 2003).

Em 2004, teve início o processo de implantação do Aterro Sanitário em Tangará da Serra, pois o lixão vinha apresentando problemas para a comunidade vizinha pela contaminação do lençol freático e produção de fumaça ocasionada pela queima dos materiais. Diante disso, a sociedade civil e os moradores do entorno iniciaram os debates sobre esses problemas e pediram intervenção do Ministério Público para obrigar o poder público local a implantar o aterro sanitário com disposição final correta para os resíduos. Não havia, por parte da comunidade nem por parte dos órgãos públicos, a preocupação com a inclusão socioprodutiva de Catadores/as que trabalhavam em condições precárias dentro do lixão.

Com a implantação, os/as Catadores/as de materiais recicláveis que trabalhavam no lixão passaram a desenvolver suas atividades produtivas e laborais no Aterro Sanitário. Embora ainda desorganizados formalmente, apresentaram resistência em sair do local, visto que não tinham onde desenvolver suas atividades. Por outro lado, a Secretaria Estadual de Meio Ambiente (SEMA) exigia, como pré-requisito para a emissão do licenciamento ambiental do Aterro Sanitário, a retirada desses trabalhadores do local (SGUAREZI et al., 2011).

Para minimizar a quantidade de resíduos que era destinada para o aterro, em 2005 foi implementado o Programa Tangará Recicla, que dispõe sobre a coleta seletiva, com objetivo de sensibilizar a população para separar adequadamente os RSU e classificar os materiais recicláveis. Esse programa corroborou para fazer a inclusão socioprodutiva de Catadores/as de materiais recicláveis e possibilitou o licenciamento ambiental do Aterro Sanitário. De acordo com o Gestor Público, "foi escolhido o bairro Cohab Tarumã para servir de projeto piloto, foram realizadas diversas adaptações nesse projeto, posteriormente, houve a ampliação da coleta seletiva em toda cidade".

Começou da prática, mas já é o começo! Foi feito o aterro sanitário para acabar com o lixão, para atender o prazo estipulado na Lei 12.305/2010. Depois entrou a coleta seletiva para poder diminuir as entradas de resíduos no aterro. Para tirar os catadores que trabalhavam no lixão, teve um acordo que foi firmado com eles, foi disponibilizado um barracão que a prefeitura fez em parceria com a cooperativa e iniciou a coleta seletiva, mas não tinha isso por escrito, só foi feito o projeto do aterro sanitário. $O$ projeto de coleta seletiva começou na prática, [...] não teve planejamento de início, meio e fim né. A coleta começou em um bairro, depois passou para toda cidade. Passou por uma questão de vontade política mais do que por uma questão de prática ou de planejamento (GP).

Entre 2005 e 2007, os/as Catadores/as, por iniciativa própria, buscaram a constituição de sua organização, mas não conseguiram avançar. Segundo Sguarezi et al. (2011), houve pelo menos duas iniciativas, a criação da Cooperativa de Reciclagem do Aterro Sanitário de Tangará da Serra (COOPERAT), com a assembleia de fundação, que ocorreu no dia 10 de fevereiro de 2005, e logo em seguida, em 17 de julho de 2005, foi formada a Associação de Catadores de Material Reciclável de Tangará da Serra (ASCAMARTAS). No entanto, a organização só se efetivou em 2007, com a fundação da Cooperativa de Produção de Material Reciclável de Tangará da Serra (COOPERTAN), que passou a operar a coleta seletiva. Em 2013, após a aprovação da PNRS/2010, houve a implementação do PMGIRS, que aparece como evento importante nas narrativas dos entrevistados, principalmente dos gestores públicos:

Houve o envolvimento da Cooperativa de Catadores/as para o processo de implementação da PMGIRS. Teve ampla discussão com as partes envolvidas; preocupações financeiras foram amplamente discutidas; o processo de coleta seletiva 
dentro do PMGIRS mereceu grandes preocupações, como por exemplo: como coletar? quem vai separar os materiais? custo da coleta seletiva, e outros (GP).

Foram várias preocupações: a adesão por parte da população e empresas do município; a questão da logística reversa, também da criação da cooperativa e o entendimento de seus integrantes; a questão da sustentabilidade do projeto através da instituição da Taxa de Resíduos Sólidos criada pelo poder executivo e aprovada pela Câmara de vereadores (GP). Na minha concepção foi a questão do catador, de você ter de retirar o catador dos lixões, e depois de retirar o catador do aterro sanitário, acho que o ponto principal foi de retirar a pessoa de uma condição insalubre. O ponto principal foi a própria pessoa, o catador (GP).

Percebem-se nas narrativas dos gestores, algumas preocupações com o financiamento da política pública da gestão de RSU em geral, mas não se pensa um financiamento exclusivo para a coleta seletiva. Existe a preocupação com a questão ambiental de destinar os RSU de forma adequada, em operacionalizar a gestão da política pública para que pudesse haver sustentabilidade. No que se refere à inclusão socioprodutiva de Catadores/as, pode ser observado o que segue:

A questão prioritária foi a inclusão dos/as Catadores/as. Acredito que algumas coisas foram sendo pensadas ao longo da operacionalidade da coleta seletiva, não houve um planejamento inicial. Tem várias outras coisas aí que não foi pensado, principalmente, quando se tem um material reciclável, para onde vai vender esse material para gerar dinheiro para o catador? De que forma que o material vai chegar até uma cooperativa? De que forma esse material vai ser vendido? Vai ser prensado? Quem vai subsidiar isso? Primeiro precisamos saber o que fazer com os produtos e depois tirar os/as Catadores/as do lixão (GP).

Cotejando a fala do Gestor Público com as iniciativas não exitosas da organização, pode-se afirmar que o êxito da coleta seletiva se dá a partir do momento que os/as Catadores/as passaram a serem sujeitos do processo. No momento da criação da COOPERTAN, no processo de organização de Catadores/as, eles passaram a participar da implementação da política, passaram a ser ouvidos no que se refere a essa operacionalização. Fatores políticos, econômicos e sociais foram citados durante a entrevista:

Quanto aos fatores políticos quando da implantação da coleta seletiva, a Prefeitura Municipal de Tangará da Serra, gestão 2005-2008, por meio da autarquia do SAMAE, bem como a Câmara Municipal de Tangará da Serra, tinham grande sensibilidade para com o tema ligado à política de resíduos sólidos e inclusão de Catadores/as, o que facilitou todo o processo de implementação. No quesito fatores econômicos, a Prefeitura Municipal tinha os recursos necessários para a implementação. Fatores sociais: grande mobilização dos stakeholders, sendo, Prefeitura Municipal de Tangará da Serra, gestão 2005-2008, por meio da autarquia do SAMAE; Câmara Municipal de Tangará da Serra, 2005-2008; Ministério Público, Banco do Brasil, La Comuna, UNEMAT Campus de Tangará da Serra, com destaque para o grupo de pesquisa NECOMT; e Movimento de Bairro (GP).

Com o início do Programa Tangará Recicla foi estimulada a coleta seletiva, a criação e a consolidação da COOPERTAN como organização de Catadores/as, que passaram a participar ativamente do processo de planejamento da política pública. Embora nem sempre o poder público local atenda às demandas da cooperativa e de seus sócios no que se refere à melhoria da política, existe um diálogo bastante produtivo entre a COOPERTAN, o SAMAE, a Prefeitura Municipal e a Câmara de Vereadores.

A concretização da Cooperativa se deu muito em virtude da parceria estratégica firmada entre ela e o SAMAE, articulada pela UNEMAT/NECOMT, o que vem fortalecendo a política pública de resíduos sólidos do município ao mesmo tempo em que garante a inclusão socioprodutiva dos trabalhadores. Assim, foi necessária a mobilização de entidades e instituições que pudessem contribuir no processo de organização dos/as Catadores/as. A UNEMAT/NECOMT passou a liderar esse processo de incubação da COOPERTAN e 
também a articular a política pública do Programa Tangará Recicla, isso permitiu que o poder público passasse a considerar, senão no todo, ao menos em parte, a demanda dos/as Catadores/as. Em 2011, com a criação da Incubadora de Organizações Coletivas Autogeridas, Solidárias e Sustentáveis (IOCASS), esta passou a assumir a articulação. Fato é que a UNEMAT/NECOMT, e depois a IOCASS, ao longo da história da COOPERTAN, se constituíram as principais parceiras da cooperativa.

Outro parceiro fundamental da COOPERTAN foi o Núcleo de Políticas para Economia Solidária (NUPES), que, por meio do Programa Municipal de Economia Solidária, promove o apoio do poder público para sua organização, formação e capacitação, o que permite tornar-se realidade o fortalecimento organizativo deste Empreendimento Econômico Solidário. O NUPES também dialoga muito fortemente com a UNEMAT/NECOMT/IOCASS no processo de organização dos Empreendimentos Econômicos Solidários (EES) em Tangará da Serra, especialmente a COOPERTAN.

Em 2010, o Programa Tangará Recicla foi ampliado, contemplando a coleta seletiva em $100 \%$ dos domicílios urbanos para atender à Lei 149/2010. A coleta seletiva também foi contemplada no Plano Diretor, de 2015 (TANGARÁ DA SERRA, 2010, 2015). O programa não dispõe de Lei específica, ele está vinculado ao PMGIRS. Evidencia-se que o município não tem uma política de financiamento específico para a coleta seletiva, não garante um orçamento específico para o programa.

O município, por meio do SAMAE, promove a inclusão socioprodutiva via contratação da Cooperativa de Catadores/as, além disso, constatou-se que a experiência, mesmo com suas limitações, é referência estadual e nacional. Em julho de 2021, a COOPERTAN chega a 14 anos de fundação, com 53 cooperados em seu quadro de sócios. Em 2020, a cooperativa obteve receita de vendas de $\mathrm{R} \$ 557.734,41$ no ano, isso é o resultado da coleta seletiva realizada por meio do contrato junto ao SAMAE.

Quanto ao PMGIRS de Tangará da Serra, o plano foi elaborado em 2013 e aprovado pelo Decreto 217, de 20 de julho de 2015. Deveria ser atualizado seguindo o disposto no art. 50, § 10 da Lei no $12.305 / 2010^{2}$. Os aspectos principais abordados no Plano Municipal, Intermunicipal ou Simplificado de Gestão Integrada de Resíduos Sólidos, incluem o diagnóstico da situação dos resíduos sólidos gerados no respectivo território, com sua caracterização e a dos agentes envolvidos, desenvolvidos em um processo participativo. Contudo, mesmo com a participação da população na separação do material reciclável, e da comunidade ter aderido à coleta seletiva, existe pouca participação da população na construção da política pública.

A Gestão de Resíduos Sólidos passou a ser pauta de discussão e chamou a atenção dos governos locais quando os municípios passaram a perceber a contaminação ambiental, os problemas de saúde da população e dos/as Catadores/as, bem como os impactos sociais negativos provenientes da atividade laboral de Catadores/as em condições precárias, arriscadas e insalubres. Os PMGIRS devem ser formulados e implementados de forma ampla, participativa e transparente, com o envolvimento de todos os cidadãos e atores que atuam direta e indiretamente com a gestão integrada de resíduos sólidos no âmbito local (BRASIL, 2010). Nos quatro municípios, não se pode afirmar que foi amplamente participativo por toda a

$2 \S 1$ 으 Os PMGIRS deverão ser atualizados ou revistos, prioritariamente, de forma concomitante com a elaboração dos Planos Plurianuais 
sociedade, mas as redes de atores se mobilizaram para buscar soluções para equacionar o problema do lixão das cidades. Esses atores sociais participaram amplamente nas discussões dos PMGIRS, dos programas de coleta seletiva e na inclusão socioprodutiva de Catadores/as. A atuação nas questões da coleta seletiva e da logística reversa faz parte do planejamento estratégico do Ministério Público, isso é fundamental para o trabalho de valorização e preservação do meio ambiente. A esse respeito, Monteiro (2004) argumenta que a rede de apoio é resultado de esforço e vontade voluntária dos cidadãos de diferentes segmentos distintos, tanto as instituições coercitivas do Estado quanto as instituições do mercado, mobilizando cidadãos por causas públicas e promovendo a estabilidade e democracias por meio de sua atuação. Pode ser percebido que os conhecimentos e percepções individuais dos implementadores de política influenciam a ação institucional resultando na implementação dos PMGIRS.

Os quatro municípios que comportam a análise dessa investigação deram início à gestão integrada de resíduos sólidos com a implantação da atividade de coleta seletiva antes mesmo do marco legal da PNRS/2010. Porém, apenas dois, Tangará da Serra (2005) e Colíder (2008), embora com limitações, iniciaram a inclusão socioprodutiva de Catadores/as de materiais recicláveis antes da PNRS, e operam com coleta de $100 \%$ dos RSU. Mesmo que importantes, as iniciativas da coleta seletiva em Cuiabá não seguiram o que prevê a gestão integrada de resíduos sólidos.

Pode-se entender que, para a execução da coleta seletiva nesses municípios, desde a implantação do Aterro Sanitário até a organização dos trabalhadores, houve preocupação com a inclusão socioprodutiva destes. Embora o poder público nem sempre soubesse lidar de forma adequada com a situação, a preocupação da política e do Gestor Público esteve presente. Para que houvesse êxito na saída dos/as Catadores/as do lixão foi necessário quebrar a resistência de algumas pessoas que insistiam em continuar trabalhando lá, necessitou-se de uma linha de comunicação com tais trabalhadores, em alguns casos formação-educação, para que houvesse a consolidação da inclusão dessas pessoas em definitivo. Isso se deu pela organização da cooperativa e da coleta seletiva.

Pode-se inferir que os municípios de Colíder, Rondonópolis e Tangará da Serra tiveram maior comprometimento por parte da gestão pública na inclusão dos indivíduos que trabalhavam na catação no lixão, instalando-os em Usinas de triagem, disponibilizando treinamento, formação em associativismo e cooperativismo, firmando acordos e contratos para a prestação de serviços e a continuidade nas gestões. Em Colíder e Rondonópolis, as organizações de Catadores/as não têm contrato para fazer a coleta seletiva, apenas para fazer a triagem e comercializar o material que tem mercado. Porém nem sempre o resultado da triagem que gera a venda dos produtos recicláveis alcança viabilidade econômica para garantir o bom funcionamento das associações e cooperativas.

Os municípios estudados possuem os Planos de Saneamento Básico e PMGIRS e atendem às exigências legais, tanto da Lei 11.445/2007 quanto da Lei 12.305/2010, dessa forma, o componente resíduo sólido está devidamente contemplado. Assim, os municípios poderão pleitear recursos da área de saneamento também para a realização dos investimentos relacionados à RGS. Por isso a PNRS incentiva a elaboração de PMGIRS como acesso de recursos para a realização de obras e a prestação de serviços no setor, possibilitando adoção de medidas de melhoria do desempenho, otimização dos recursos financeiros 
investidos em áreas previstas pela política ambiental dos municípios, auxilia na aplicação de instrumentos legais e integra outros requisitos de natureza ambiental necessários ao processo de gestão de RSU (VENTURA et al., 2020).

Foi possível observar que Tangará da Serra possui um programa de inclusão socioprodutiva de Catadores/as reconhecido e consolidado. Nesse município, a Coopertan presta serviços de coleta, transporte e triagem dos recicláveis para $100 \%$ dos domicílios e dos grandes geradores. No entanto, é necessário formalizar uma política pública específica para coleta seletiva que garanta o financiamento da atividade. É preciso criar um fundo de investimentos para a gestão e financiamento da coleta seletiva de RSU, seja por fonte específica ou sistema de cobrança dos resíduos, sendo devidamente geridos, visto que o Programa Tangará Recicla, mesmo que esteja integrado ao PMGIRS, não prevê o financiamento específico da atividade.

Diferentemente dos demais municípios, Cuiabá ainda enfrenta grandes dificuldades para incluir os/as Catadores/as que trabalham no aterro sanitário. A inserção desses trabalhadores em associação/cooperativa deve ser acompanhada de incentivos e investimentos. As atividades desempenhadas nas organizações autogestionárias representam hoje a alternativa a ser escolhida pelo legislador para a integração social desses trabalhadores, para atender à PNRS/2010. São possibilidades de inserção social que lhes têm permitido recuperar a dignidade e a autoestima (GAIGER, 2003). Desse modo, é necessário o fortalecimento dessas organizações com apoio e cooperação do governo, de modo a possibilitar a transformação da realidade social dos/as Catadores/as (SILVEIRA, 2019).

Percebe-se, nos municípios em estudo, a presença de Catadores/as individuais, em especial, em Cuiabá, com trabalhadores no lixão. Ribeiro e Cantóia (2020) expressam que:

A informalidade do trabalho promove essa precarização das condições de trabalho e a vulnerabilidade dos catadores de recicláveis, essa falta de segurança também está relacionada à procura dos resíduos mais rentáveis, os catadores ficam misturados ao lixão, enquanto ocorre concomitantemente aos processos de descarregamento pelo caminhão da prefeitura e a compactação pelos tratores esteiras de prensagem (RIBEIRO; CANTÓIA, 2020).

Essas condições inadequadas às quais os autores se referem, além de expor os trabalhadores diariamente a condições vulneráveis, insalubres e de periculosidade, geram impactos ambientais. Entendese que é fundamental a efetivação de metas para a construção do aterro sanitário com inclusão social e produtiva de Catadores/as de modo a cumprir com as normativas estabelecidas pela PNRS (2010) e minimizar os impactos causados pela disposição inadequada (RIBEIRO et al., 2020).

A pesquisa mostrou que certos fatores dificultam as organizações de Catadores/as nos municípios, como: o mercado de alguns produtos recicláveis é deficitário e outros produtos não apresentam viabilidade econômica devido ao valor de frete ser maior que o preço de venda da carga de produtos, é o caso do vidro, do isopor e de outros. Os municípios apresentam deficiência na logística reversa de diversos materiais, bem como falta de acordo setorial para diversos tipos de embalagens. Costa et al. (2006), Couto et al. (2017), Fernandes et al. (2017), Chaves et al. (2019) asseguram que a logística reversa vem contribuir de forma significativa nos projetos urbanos de preservação e conservação do meio ambiente, além da 
manutenção dos aterros sanitários, grande problema da atualidade em grandes centros urbanos e até para as pequenas cidades, e primordial para a sustentabilidade.

Observou-se uma forte concorrência no mercado de recicláveis nos municípios pesquisados. Os/as Catadores/as expressaram que mesmo nos municípios onde a coleta seletiva é porta a porta passa por um filtro da força informal de mercado, que se inicia nas residências, na separação do material que tem maior valor agregado e são vendidos para o mercado informal, também por Catadores/as de rua que rasgam a sacola da reciclagem para coletar as latinhas e os materiais com maior valor, e esses materiais acabam sendo vendidos para atravessadores em mercado informal. Assim, a maioria dos materiais que vão para as organizações formais de Catadores/as, mesmo sendo recicláveis, têm baixo valor de mercado. Isso foi observado também por Silveira (2019), na cidade do Rio de Janeiro.

Autores como Aquino et al. (2009), Ribeiro et al. (2009) e Demajorovic et al. (2014) expressam que a integração de organização de Catadores/as no fornecimento de materiais recicláveis para as empresas também apresenta uma série de dificuldades, devido à escassez de infraestrutura e de equipamentos que permitam coletar, processar e armazenar grandes quantidades de resíduos, impossibilitando as vendas diretas para a indústria, assim, acabam sendo vendidos para atores intermediários da cadeia reversa, comprometendo seus ganhos e a própria sustentabilidade de suas operações.

Pode-se inferir que um dos principais problemas da coleta seletiva de RSU nos municípios pesquisados, e um grande desafio para as gestões municipais, é a deficiência na educação ambiental. Essa relação entre comportamentos e atitudes da população e o desempenho da reciclagem a partir da coleta seletiva, mesmo em municípios como Tangará da Serra e Colíder, que têm coleta seletiva porta a porta em 100\% na área urbana, é problemática, existe um universo de pessoas que não faz a separação corretamente e acaba destinando materiais recicláveis para o aterro sanitário. Bringhenti et al. (2011) citam vários estudos que apresentam essa mesma deficiência. A destinação do material adequadamente separado para as organizações contribui para que a taxa de rejeitos seja reduzida (BESEN, 2014).

Nesse aspecto, Carvalho (2017) também argumenta que a educação ambiental é uma maneira de repensar as relações do homem com a natureza e um instrumento de transformação social para um desenvolvimento sustentável. Silva (2018) complementa que inclui também um conjunto de componentes, como conscientização, sensibilização, conhecimento, atitudes e habilidades para identificar os desafios ambientais, bem como participação em atividades que levem à sua resolução. É fundamental que os indivíduos desenvolvam uma compreensão mais profunda das questões ambientais e tenham as habilidades para tomar decisões informadas e responsáveis (VARELA-CANDAMIO et al., 2018).

\section{CONCLUSÕES}

Os resultados apontaram que, nos quatro municípios investigados, os gestores públicos e a sociedade civil iniciaram a discussão do processo de coleta seletiva e adequação da política pública local de gestão dos RSU antes da Lei no 12.305/2010. Percebeu-se que esses municípios, no momento da criação das políticas públicas, já possuíam a preocupação com o teor social, com a inclusão socioprodutiva de Catadores/as, ao se referir a uma categoria de indivíduos que sobrevivem da coleta e da comercialização de 
resíduos. Dos quatro analisados, dois municípios Tangará da Serra e Colíder, se mostraram mais exitosos na inclusão socioprodutiva de Catadores/as de materiais recicláveis, iniciando esse processo ainda antes da PNRS.

Sendo responsabilidade da administração municipal a coleta e disposição dos resíduos, os municípios necessitam de ações contínuas de educação ambiental, de forma a modificar os hábitos de descarte da população visando o aumento da eficiência da coleta seletiva. Os entes públicos também devem assegurar que a logística reversa seja efetivada, de modo a possibilitar a redução da quantidade de produção de RSU e destinação ao aterro sanitário; devem buscar fonte específica de financiamento para a gestão de resíduos sólidos; bem como o aprimoramento de técnicas e de prática de reciclagem, aquisição de máquinas e equipamentos e maior responsabilidade das empresas com a logística reversa e com os objetivos da PNRS, a fim de melhor aproveitamento do material reciclável. É preciso que o poder público, nesse caso, assuma um papel orientador, não apenas fiscalizador.

Quanto à inclusão socioprodutiva de Catadores/as, mesmo com escassos investimentos na coleta seletiva, apresentam resultados positivos em relação à questão social, econômica, ambiental e política. Portanto, em todos os municípios, faz-se necessária à implementação de políticas públicas locais que invistam na gestão integrada de resíduos sólidos urbanos e na inclusão socioprodutiva de Catadores/as na coleta seletiva, de forma a garantir a consolidação de contratos administrativos entre os municípios e as organizações de Catadores/as, com justa remuneração aos serviços prestados, que proporcionem melhores condições de trabalho e de vida para os indivíduos que fazem da reciclagem o seu trabalho. É necessário universalizar a coleta seletiva de resíduos e utilizar tecnologias adequadas para reaproveitamento e reciclagem, visto que isso garante uma maior vida útil dos aterros sanitários e a redução dos custos com a gestão desses serviços.

\section{REFERÊNCIAS}

ANDRADE, A. S. M.. O discurso do pioneirismo e suas representações: Tangará da Serra, MT (1976-1997). Dissertação (Mestrado em Educação) - Pontifícia Universidade Católica do Rio Grande do Sul, Porto Alegre, 2009.

APARCANA, S.. Approaches to formalization of the informal waste sector into municipal solid waste management systems in low-and middle-income countries: review of barriers and success factors. Waste management, v.61, p.593-607, 2017.

AQUINO, I. F.; CASTILHO JR., A. B.; PIRES, T. S. L. A.. organização em rede dos catadores de materiais recicláveis na cadeia produtiva reversa de pós-consumo da região da grande Florianópolis: uma alternativa de agregação de valor. Gestão e Produção, v.16, n.1, p.15-24, 2009. DOI: https://doi.org/10.1590/S0104-530X2009000100003

BAPTISTA, V. F.. As políticas públicas de Coleta seletiva no município do Rio de Janeiro: onde e como estão as cooperativas de catadores de materiais recicláveis? Revista de administração pública, v.49, n.1, p.141-164, 2015. DOI: https://doi.org/10.1590/0034-76121603
BESEN, G. R.; RIBEIRO, H.; GUNTHER, W. M. R.; JACOBI, P. R.. Coleta seletiva na região metropolitana de São Paulo: impactos da Política Nacional de Resíduos Sólidos. Ambiente \& Sociedade, v.17, n.3, p.259-278, 2014. DOI: http://dx.doi.org/10.1590/S1414-753X2014000300015

BRASIL. Lei no 12.305. Política Nacional de Resíduos Sólidos. Brasília: DOU, 2010.

BRINGHENTI, J. R.; RISSO GUENTHER, W. M.. Social participation in selective collection program of municipal solid waste. Engenharia Sanitária e Ambiental, v.16, n.4, p. 421-430, 2011. DOI: http://dx.doi.org/10.1590/S141341522011000400014

CARVALHO, I. C. M.. Educação ambiental: a formação do sujeito ecológico. São Paulo: Cortez Editora, 2017.

CASTILHOS JUNIOR, A. B.; RAMOS, N. F.; ALVES, C. M.; FORCELLINI, F. O.; GRACIOLLI, O. D.. Catadores de materiais recicláveis: análise das condições de trabalho e infraestrutura operacional no Sul, Sudeste e Nordeste do Brasil. Revista Ciência \& Saúde Coletiva, v.18, n.11, p.31153124, 2013. DOI: http://dx.doi.org/10.1590/S141381232013001100002 
CLEARY, J.. Life cycle assessments of municipal solid waste management systems: a comparative analysis of selected peer-reviewed literature. Environment international, v.35, n.8, p.1256-1266, 2009. DOI: https://doi.org/10.1016/j.envint.2009.07.009

COSTA, I. M.; DIAS, M. F.. Evolution on the solid urban waste management in Brazil: a portrait of the Northeast Region. Energy Reports, v.6, p.878-884, 2020. DOI: https://doi.org/10.1016/i.egyr.2019.11.033

DEMAJOROVIC, J.; CAIRES, E. F.; GONÇALVES, L. N. S.; SILVA, M. J. C.. Integrando empresas e cooperativas de catadores em fluxos reversos de resíduos sólidos pós-consumo: o caso Vira-Lata. Cadernos Ebape, v.12, p.513-532, 2014. DOI: http://dx.doi.org/10.1590/1679-39519020

DOWBOR, L.. 0 capitalismo se desloca: novas arquiteturas sociais. São Paulo: Sesc, 2020.

DUARTE, D. P.. Gestão de resíduos sólidos e catadores: contribuições para o desenvolvimento sustentável. In: ENCONTRO EM ENGENHARIA DE EDIFICAÇÕES E AMBIENTAL, 2. Anais. Cuiabá, 2014.

GALON, T. E.; MARZIALE, M. H. P.. Condições de trabalho e saúde de catadores de materiais recicláveis na América Latina: uma revisão de escopo. In: PEREIRA, B. C. J.; GOES, F. L.. Catadores de Materiais Recicláveis: um encontro nacional. Brasília: IPEA, 2016, p.169-199.

HOORNWEG, D.. What a Waste: a Global. Review of Solid Waste Management, World Bank, 2012

IPEA. Instituto de Pesquisa Econômica Aplicada. Pesquisa sobre pagamento por serviços ambientais urbanos para gestão de resíduos sólidos. Brasília: IPEA, 2010.

IPEA. Instituto de Pesquisa Econômica Aplicada. A inclusão produtiva como eixo de política de proteção social: contexto latino-americano e questões para a realidade brasileira. Brasília: IPEA, 2020.

JACOBI, P. R.. Gestão compartilhada dos resíduos sólidos no Brasil: inovação com inclusão social. Annablume, 2006.

JACOBI, P. R.; BESEN, G. R.. Gestão de resíduos sólidos em São Paulo: desafios da sustentabilidade. Estudos avançados, v.25, n.71, p.135-158, 2011.

KRINSKI, D.; MIYAZAWA, C. S.. Peixes de riachos de cabeceira de Tangará da Serra - Mato Grosso: lista de espécies e abordagem citogenética. Cuiabá: KCM, 2009.

LEFF, E.; ARGUETA, A.; BOEGE, E.; GONÇALVES, C. W.. Más allá del desarrollo sostenible. La construcción de una racionalidad ambiental para la sustentabilidad: una visión desde América Latina. In: LEFF, E.; EZCURRA, E.; PISANTY, I.; ROMERO, P.. La transición hacia el desarrollo sustentable: perspectivas de América Latina y el Caribe, 2002.

LOHRI, C. R.; CAMENZIND, E. J.; ZURBRÜGG, C.. Financial sustainability in municipal solid waste management-Costs and revenues in Bahir Dar, Ethiopia. Waste management, $v$. 34, n.2, p.542-552, 2014. DOI:

https://doi.org/10.1016/j.wasman.2013.10.014

MIEZAH, K.; OBIRI-DANSO, K.; KÁDÁR, Z.; FEI-BAFFOE, M. $M$.. Municipal solid waste characterization and quantification as a measure towards effective waste management in Ghana. Waste Management, v.46, p.15-27, 2015. DOI: https://doi.org/10.1016/i.wasman.2015.09.009

MIYAZAKI, T. Y.; VILALVA, W.. Relatos de uma saga: pioneiros de Tangará da Serra-MT. Discursos e linguagens: objetos de análise e perspectivas teóricas, v.6, p.10-14, 2012.

NOBREGA, C. C.. Avaliação do ciclo de vida da Coleta seletiva de papel e papelão no núcleo do Bessa, município de João Pessoa (PB), Brasil. Engenharia Sanitária e Ambiental, v.24, n. 5, p.875-886, 2019. DOI: https://doi.org/10.1590/s141341522019197802

OLIVEIRA, J. A. P.. Intergovernmental relations for environmental governance: cases of solid waste management and climate change in two Malaysian States. Journal of environmental management, v.233, p.481-488, 2019. DOI: https://doi.org/10.1016/j.jenvman.2018.11.097

OLIVEIRA, L. B.; ROSA, L. P.. Brazilian waste potential: energy, environmental, social and economic benefits. Energy Policy, v.31, n.14, 2018. DOI: https://doi.org/10.1016/S0301-4215(02)00204-5

PAES, M. X.. Municipal solid waste management: Integrated analysis of environmental and economic indicators based on life cycle assessment. Journal of Cleaner Production, v.254, p.119-848, 2020. DOI: https://doi.org/10.1016/i.jclepro.2019.119848

PEREIRA, J. A.. Mapa do Conhecimento Gestão Residual. In: ENGEMA, ENCONTRO INTERNACIONAL SOBRE GESTÃO EMPRESARIAL E MEIO AMBIENTE. Anais. Universidade de São Paulo, São Paulo, 2016.

PEREIRA, M. A. O.. Análise da gestão da gestão de resíduos sólidos urbanos: uma discussão sobre o processo de mudanças em Colíder, Mato Grosso, Brasil. Dissertação (Mestrado em Ciências Ambientais) - Universidade do Estado de Mato Grosso, Cáceres, 2014.

PRESSMAN, J. L.; WILDAVSKY, A.. Implementation. 3 ed. Berkeley: University of California, 1984.

RIBEIRO, H.; JACOBI, P. R.; BESEN, G. R.; GUNTHER, W. M. R.; DEMAJOROVIC, J.; VIVEIROS, M.. Coleta seletiva com inclusão social: cooperativismo e sustentabilidade. São Paulo: Annablume, 2009.

RIBEIRO, N. L. D.; CANTÓIA, S. F.. O lixão de Cuiabá e a geração de impactos socioambientais. Geosaberes, v.11, p. 100-115, 2020. DOI:

https://doi.org/10.26895/geosaberes.v11i0.778

RIBEIRO, H.; JAIME, P. C.; VENTURA, D.. Alimentação e sustentabilidade. Estudos avançados, v.31, n.89, p.185-198, 2017. DOI: http://dx.doi.org/10.1590/s010340142017.31890016

SABATIER, P. A.. Top-Down and Bottom-Up Approaches to Implementation Research: a Critical Analysis and Suggested Synthesis. Journal of Public Policy, v.6, n.1, p.21-48, 1986.

SANTOS, T. F.. Reflexões sobre as políticas públicas voltadas aos (às) catadores (as) de materiais recicláveis no estado da Paraíba. Revista Brasileira de Políticas Públicas e Internacionais, v.3, n.1, p.206-229, 2018. DOI: https://doi.org/10.22478/ufpb.2525-5584.2018v3n1.35429

SAMAE. Serviço Autônomo Municipal de Água e Esgoto. 
Plano Municipal de Gestão Integrada de Resíduos Sólidos (PMGIRS) do Município de Tangará da Serra /MT. São Paulo, 2013.

SGUAREZI, S. B.; LAFORGA, G.. Desafios e contradições no processo de incubação da Cooperativa de Produção de Material Reciclável de Tangará da Serra-MT. In: ZANIN, M.; GUTIERREZ, R. F.. Cooperativa de Catadores: reflexões sobre as práticas. São Carlos: Claraluz, 2011, p.283-322.

SGUAREZI, S. B.. Epistemologias do Sul: interfaces entre autogestão, transconhecimento, transustentabilidade. In: RODRIGUES, A. S.; FRANÇA, R.. Epistemologias do Sul: estudos de literatura, línguas e educação. Cáceres: UNEMAT Editora, 2014.

SGUAREZI, S. B.. Autogestão: histórico da organização coletiva do trabalho na COOPERTAN. Revista Territórios e Fronteiras, v.3, n.2, p.212-226, 2010.
SILVA, S. P.. O campo de pesquisa da economia solidária no Brasil: abordagens metodológicas e dimensões analíticas. Rio de Janeiro: IPEA, 2018.

SOUZA, C.. Políticas públicas: uma revisão da literatura. Sociologias, n.16, p.20-45, 2006.

VENTURA, K. S.; SUQUISAQUI, A. B. V.. Aplicação de ferramentas SWOT e 5W2H para análise de consórcios intermunicipais de resíduos sólidos urbanos. Ambiente Construído, v.20, n.1, p.333-349. 2020. DOI: http://dx.doi.org/10.1590/s1678-86212020000100378

XIMENES MELO, S. A. B.; SGUAREZI, S. B.. Políticas públicas: coleta seletiva de resíduos sólidos urbanos em Tangará da Serra/MT - Brasil. In. SGUAREZI, S. B.. Ambiente e Sociedade no Brasil Central: diálogos Interdisciplinares e Desenvolvimento Regional. Cáceres: Editora UNEMAT, 2019, p.86-103.

A CBPC - Companhia Brasileira de Produção Científica (CNPJ: 11.221.422/0001-03) detém os direitos materiais desta publicação. Os direitos referem-se à publicação do trabalho em qualquer parte do mundo, incluindo os direitos às renovações, expansões e disseminações da contribuição, bem como outros direitos subsidiários. Todos os trabalhos publicados eletronicamente poderão posteriormente ser publicados em coletâneas impressas sob coordenação da Sustenere Publishing, da Companhia Brasileira de Produção Científica e seus parceiros autorizados. Os (as) autores (as) preservam os direitos autorais, mas não têm permissão para a publicação da contribuição em outro meio, impresso ou digital, em português ou em tradução. 